\title{
CONTRASTS IN AREAS OF RUBBER TREE CLONES IN REGARD TO SOIL AND BIOMASS CARBON STOCKS
}

\author{
Anderson Ribeiro Diniz ${ }^{(1)}$, Marcos Gervasio Pereira ${ }^{(2) *}$, Fabiano de Carvalho Balieiro ${ }^{(3)}$, \\ Eduardo Vinicius da Silva ${ }^{(4)}$, Felipe Martini Santos ${ }^{(5)}$, Francy Junio Gonçalves Lisboa ${ }^{(1)}$, Aldo \\ Bezerra de Oliveira ${ }^{(6)}$ and Renato Barbosa da Cruz ${ }^{(6)}$
}

(1) Universidade Federal Rural do Rio de Janeiro, Departamento de Ciência do Solo, Programa de Pós-graduação em Agronomia, Seropédica, Rio de Janeiro, Brasil.

(2) Universidade Federal Rural do Rio de Janeiro, Departamento de Ciência do Solo, Seropédica, Rio de Janeiro, Brasil.

(3) Empresa Brasileira de Pesquisa Agropecuária, Embrapa Solos, Rio de Janeiro, Rio de Janeiro, Brasil.

(4) Universidade Federal Rural do Rio de Janeiro, Departamento de Silvicultura, Seropédica, Rio de Janeiro, Brasil.

(5) Universidade Federal Rural do Rio de Janeiro, Departamento de Silvicultura, Programa de Pós-graduação em Ciências Ambientais e Florestais, Seropédica, Rio de Janeiro, Brasil.

(6) Empresa de Pesquisa Agropecuária do Estado do Rio de Janeiro, Niterói, Rio de Janeiro, Brasil.

* Corresponding author.

E-mail: gervasio@ufrrj.br

\begin{abstract}
Rubber tree (Hevea brasiliensis) crop may accumulate significant amounts of carbon either in biomass or in the soil. However, a comprehensive understanding of the potential of the $\mathrm{C}$ stock among different rubber tree clones is still distant, since clones are typically developed to exhibit other traits, such as better yield and disease tolerance. Thus, the aim of this study was to address differences among different areas planted to rubber clones. We hypothesized that different rubber tree clones, developed to adapt to different environmental and biological constrains, diverge in terms of soil and plant biomass $\mathrm{C}$ stocks. Clones were compared in respect to soil $\mathrm{C}$ stocks at four soil depths and the total depth $(0.00-0.05,0.05-0.10$, 0.10-0.20, 0.20-0.40, and 0.00-0.40 m), and in the different compartments of the tree biomass. Five different plantings of rubber clones (FX3864, FDR 5788, PMB 1, MDX 624, and CDC 312) of seven years of age were compared, which were established in a randomized block design in the experimental field in Rio de Janeiro State. No difference was observed among plantings of rubber tree clones in regard to soil $\mathrm{C}$ stocks, even considering the total stock from $0.00-0.40 \mathrm{~m}$ depth. However, the rubber tree clones were different from each other in terms of total plant $\mathrm{C}$ stocks, and this contrast was predominately due to only one component of the total
\end{abstract}


C stock, tree biomass. For biomass C stock, the MDX 624 rubber tree clone was superior to other clones, and the stem was the biomass component which most accounted for total $\mathrm{C}$ biomass. The contrast among rubber clones in terms of $\mathrm{C}$ stock is mainly due to the biomass $\mathrm{C}$ stock; the aboveground (tree biomass) and the belowground (soil) compartments contributed differently to the total $\mathrm{C}$ stock, 36.2 and $63.8 \%$, respectively. Rubber trees did not differ in relation to $\mathrm{C}$ stocks in the soil, but the right choice of a rubber clone is a reliable approach for sequestering $\mathrm{C}$ from the air in the biomass of trees.

Keywords: Hevea brasiliensis, organic matter, carbon sequestration.

\section{RESUMO: CONTRASTE DE PLANTIOS CLONAIS DE SERINGUEIRA QUANTO AO ESTOQUE DE CARBONO NO SOLO E NA BIOMASSA}

A cultura da seringueira (Hevea brasiliensis) pode acumular quantidades significativas de carbono, seja na biomassa ou no solo. No entanto, ainda se está longe de uma compreensão abrangente sobre o potencial de estoque de $C$ entre os diferentes clones de seringueira, em razão de esses serem tipicamente formados para exibir outras características, como aumento de produtividade e maior tolerância às doenças. Assim, este estudo teve como objetivo abordar as diferenças entre plantios clonais de seringueira, buscando preencher a lacuna decorrente da seguinte indagação: A hipótese do estudo foi que os diferentes clones de seringueira, desenvolvidos para serem adaptados a distintas condições ambientais e biológicas, divergem em termos de estoque de $C$ no solo e na biomassa. Foram comparados os estoques de C no solo em quatro profundidades e profundidade total (0,00-0,05; 0,05-0,10; 0,10-0,20; 0,20-0,40; e 0,00-0,40 m) e nos diferentes compartimentos da biomassa arbórea. Foram comparados cinco diferentes clones de seringueira com sete anos de idade (FX 3864, FDR 5788, PMB 1, MDX 624 e CDC 312), que foram implantados em um delineamento em blocos casualizados, no campo experimental da Empresa de Pesquisa Agropecuária do Estado do Rio de Janeiro. Não foi observada diferença entre os plantios clonais de seringueira quanto aos estoques de C no solo, mesmo considerando o estoque total de 0,00-0,40 m. Diferentemente do que ocorreu no estoque de C no solo, os plantios clonais divergiram em termos de C na biomassa arbórea, com a fração tronco contribuindo majoritariamente para o total do $C$ da biomassa. Foi verificado que a biomassa arbórea e o solo contribuem diferentemente para o estoque de C total, 36,2 e 63,8\%, respectivamente. Os padrões observados indicaram que, independentemente das diferenças entre clones, o cultivo de seringueira em si pode ser interessante para elevar o estoque de $C$ do solo.

Palavras-chave: Hevea brasiliensis, matéria orgânica, sequestro de carbono.

\section{INTRODUCTION}

The increase in world population over the last number of years has mainly been due to developing countries and, as result, natural landscapes in those countries have been altered in order to meet the increasing demand for food and industrial based products (FAO, 2010). In fact, changes in land use to establish profitable tree crops is a typical example of how population increase can affect the demand for natural products and, consequently, the pressure on natural environments. Brazil was an important natural rubber manufacturer, with rubber tree (Hevea spp.) exploration as the main source (Borracha Natural Brasileira, 2014).

However, rubber production in the Amazon forest confronted two main economic challenges. The first was the high operational cost of delivering natural rubber from the Amazon to Brazilian regions with great demand for rubber. The second was the decline in rubber yield due to fungal diseases, namely "south
American leaf blight" (Gonçalves and Marques, 2008). These problems, along with increasing environmental concerns in regard to sustainable use of the Amazon forest, caused the displacement of rubber production to Brazilian areas free of the fungal disease and to areas of highest demand. These areas are in the Brazilian southeast $\left(22^{\circ} \mathrm{S}-24^{\circ} \mathrm{S}\right)$, and the establishment of rubber tree plantations outside the Amazon forest has mainly occurred in areas that have typically been used as pasture, at different levels of degradation. Such a scenario can be seen in the State of Rio de Janeiro, in which almost $20 \%$ of the total area corresponds to pastures at different levels of degradation, potentially useful for rubber tree plantations (Naime et al., 2009).

The replacement of pastures by rubber tree plantations may theoretically be important in terms of soil conservation, since authors have indicated the potential of the rubber tree plantations in storing atmospheric $\mathrm{C}$ in the soil and aboveground biomass (Cheng et al., 2007). As an example, Li et al. (2012) 
found that soil $\mathrm{C}$ levels in a 28 -year-old rubber tree plantation were $20 \%$ higher than those in a 15-year-old abandoned pasture, and $5 \%$ lower than those found in a primary tropical forest. Despite these results, proper knowledge of potential C sequestration in soils and aboveground biomass under different rubber tree plantations is still distant, given that only a few studies have focused on it (Wauters et al., 2008; Maggioto et al., 2014). Such a gap is somewhat not in line with the Brazilian goal of replacing, by 2020 , at least $28 \%$ of its soils under degraded pastures by crops for profitable land use and which are considered as environmentally better in terms of potential C sequestration, above-and/or belowground (Strassburg et al., 2014).

Carbon sequestration corresponds to net removal of $\mathrm{CO}_{2}$ from the atmosphere into different long-life $\mathrm{C}$ pools. These pools consist of plant biomass, root biomass, soil organisms, and the relatively stable forms of organic and inorganic pools found in soil (Ramachandran, 2009). Therefore, aboveground and belowground $\mathrm{C}$ sequestration are related to different plant traits, which have been shown to be affected by intraspecific variation and which, in turn, respond to a range of environmental factors (Poorter et al., 2012). Indeed, the Brazilian genetic improvement program for rubber trees pursues two main objectives: improvement of traits related to an increase in rubber yield, and adaptation of rubber clones to different environmental and biological constraints.

Such a program is not motivated by a direct and specific interest in intraspecific variation in rubber tree clones in respect to $\mathrm{C}$ sequestration; however, this is somewhat curious, since $\mathrm{C}$ sequestration is related to both above- and belowground plant compartments, which, in turn, are closely related to the photosynthetic status that regulates latex production. Thus, the aim of the current study was to address the differences among plantings of rubber clones by testing the hypothesis that they also differ from each other in terms of soil and tree biomass C stocks.

\section{MATERIAL AND METHODS}

\section{Location and characterization of the study area}

The study was conducted in7-year-old clonal plantings of Hevea brasiliensis M. Arg., here after called rubber tree clones, established in the experimental field of the Empresa de Pesquisa Agropecuária do Estado do Rio de Janeiro - Pesagro (Rio de Janeiro Agricultural Research Institute) ( $22^{\circ} 39^{\prime} 03^{\prime \prime} \mathrm{S}$ and $\left.42^{\circ} 23^{\prime} 30^{\prime \prime} \mathrm{W}\right)$. The slope of the land ranges from 18 to $23 \%$, and average elevation is about $45 \mathrm{~m}$. The climate type is Cwa, humid tropical, according to Köppen, with an average annual temperature of $23{ }^{\circ} \mathrm{C}$ and average annual rainfall of $1,500 \mathrm{~mm}$. The soil was classified as Typic Hapludult (Soil Survey Staff, 2010).

The soil of the experimental area was previously planted to citrus (Citrus sinensis L. Osbeck) for five years, and then used as pasture without any management for two years, until the planting of different clones of rubber trees (April, 2006). Each of the areas planted to five different rubber tree clones, namely FX 3864, FDR 5788, PMB 1, MDX 624 , and CDC 312 , occupied a $160 \mathrm{~m}^{2}$ plot containing eight trees $(8 \times 2.5 \mathrm{~m}$ spacing) corresponding to a density of 500 trees ha $^{-1}$. In each plot, the seedlings of the rubber tree clones were sown in plant holes $(0.40 \times 0.40 \times 0.50 \mathrm{~m})$ which were previously fertilized with $300 \mathrm{~g}$ of dolomitic limestone $(29.5 \%$ $\mathrm{CaO}, 19.5 \% \mathrm{MgO}), 300 \mathrm{~g}$ of NPK (2-16-6), and $10 \mathrm{~L}$ of bovine manure. All clone plots underwent the same fertility management after their formation.

\section{Experimental design and soil sampling}

The experiment was carried out in a randomized block design corresponding to four blocks, each one with only one replicate of the five plots of rubber tree clones (treatments). The arrangement of the blocks was perpendicular to slope orientation. Ten single samples were used to make up one composite sample, and samples were taken at random from the soil at four soil depths (0.00-0.05, 0.05-0.10, 0.10-0.20, and $0.20-0.40 \mathrm{~m}$ ). To take the existing soil slope variation in the experimental plots (8-20\%) into account, sampling for characterization of soil fertility and texture was performed for three different positions: upper, middle, and lower (Table 1).

\section{Soil carbon stock}

Within each planted area of rubber clones, two undisturbed samples were collected using a volumetric ring (Embrapa, 1997) at four different depths (0.00-0.05, 0.05-0.10, 0.10-0.20, and $0.20-0.40 \mathrm{~m})$. The first sample was used for soil density determination and the last for assessment of total organic C levels (Yeomans and Bremner, 1988).

The soil C stock (StkC) was determined using the following equation:

$S t k C=(C \times D s \times t h k) / 10$

where $S t k C$ represents the $\mathrm{C}$ stock $\left(\mathrm{Mg} \mathrm{ha}^{-1}\right), \mathrm{C}$ is the value of the total organic $\mathrm{C}$ content in the layer $\left(\mathrm{g} \mathrm{kg}^{-1}\right), D s$ is the soil bulk density $\left(\mathrm{Mg} \mathrm{m}^{-3}\right)$, and thk is the thickness of the layer under analysis (m) (Freixo et al., 2002).

\section{C stocks in the tree biomass}

Seven years after the experiment was established, a forest inventory was carried out in order to assess two variables related to tree growth - namely, diameter at breast height (DBH, measured $1.30 \mathrm{~m}$ 
Table 1. Characterization of soil properties according to the sampling position in the slope

\begin{tabular}{|c|c|c|c|c|c|c|c|c|c|c|c|c|c|c|c|c|}
\hline Position & $\mathrm{pH}\left(\mathrm{H}_{2} \mathrm{O}\right)$ & $\mathbf{P}$ & $\mathbf{K}$ & $\mathrm{Mg}^{2+}$ & $\mathrm{Ca}^{2+}$ & $\mathrm{Na}^{+}$ & $\mathrm{Al}^{3+}$ & $\mathrm{H}+\mathrm{Al}$ & SB & $\mathbf{T}$ & $\mathrm{V}$ & $\mathrm{CO}$ & Clay & Silt & Sand & Bd \\
\hline & & \multicolumn{2}{|c|}{$\mathrm{mg} \mathrm{dm^{-3 }}$} & \multicolumn{7}{|c|}{$\mathrm{cmol}_{\mathrm{c}} \mathrm{dm}^{-3}$} & $\%$ & \multicolumn{4}{|c|}{$\mathrm{g} \mathrm{kg}^{-1}$} & $\mathrm{Mg} \mathrm{m}^{-3}$ \\
\hline & \multicolumn{16}{|c|}{$0.00-0.20 \mathrm{~m}$} \\
\hline Upper & 4.7 & 1.0 & 17 & 0.8 & 1.5 & 0.0 & 1.5 & 4.6 & 2.3 & 7.0 & 32.5 & 14.8 & 271 & 119 & 610 & 1.50 \\
\hline Middle & 4.9 & 0.8 & 32 & 0.9 & 1.0 & 0.0 & 1.1 & 4.2 & 2.2 & 6.4 & 34.5 & 15.0 & 249 & 130 & 620 & 1.43 \\
\hline \multirow[t]{2}{*}{ Lower } & 4.8 & 0.9 & 28 & 0.8 & 0.6 & 0.0 & 1.3 & 4.2 & 1.7 & 5.9 & 28.8 & 15.5 & 236 & 142 & 622 & 1.47 \\
\hline & \multicolumn{16}{|c|}{$0.20-0.40 \mathrm{~m}$} \\
\hline Upper & 4.4 & 0.8 & 16 & 0.5 & 2.4 & 0.0 & 2.4 & 4.9 & 2.6 & 7.5 & 35.0 & 11.7 & 420 & 67 & 513 & 1.62 \\
\hline Middle & 4.6 & 0.4 & 26 & 0.4 & 1.0 & 0.0 & 1.6 & 4.1 & 1.4 & 5.6 & 25.9 & 13.0 & 404 & 78 & 518 & 1.58 \\
\hline Lower & 4.6 & 0.5 & 20 & 0.7 & 0.2 & 0.0 & 1.8 & 4.0 & 09 & 5.0 & 19.5 & 12.3 & 378 & 101 & 521 & 1.53 \\
\hline
\end{tabular}

$\mathrm{pH}\left(\mathrm{H}_{2} \mathrm{O}\right)$ : $\mathrm{pH}$ in water (1:2,5 v/v); P, K, Na: extracted by Mehlich-1; Ca, Mg, Al: extracted by $\mathrm{KCl} 1 \mathrm{~mol} \mathrm{~L}{ }^{-1} ; \mathrm{H}+\mathrm{Al}$ : by titration after extraction with $0.5 \mathrm{~mol} \mathrm{~L}^{-1}$ calcium acetate at $\mathrm{pH}$ 7.0; CO: organic carbon by Yeomans and Bremner (1988) method; Bd: bulk density and clay, silt, sand: particle size analysis was performed according to Embrapa (2011).

above the soil surface) and total tree height (Ht). The DBH and $\mathrm{Ht}$ were used for estimating the $\mathrm{C}$ stock in different tree biomass components (roots, stem, branches, leaves, and total). For this estimation, allometric equations were used, which were previously adapted for Hevea brasiliensis under the conditions of the Southeast of Brazil (Fernandes et al., 2007) (Table 2).

\section{Statistical analysis}

The data were previously analysed for normality and same error distribution assumptions. One-way Anova was carried out in order to test the general null hypothesis that the soil and tree biomass $\mathrm{C}$ variables across different plantings of rubber tree clones came from the same population. The mean values were compared by the Tukey test at $\mathrm{p}<0.05$.

\section{RESULTS}

\section{Soil C stocks}

There was no difference among the plantings of rubber tree clones for either $\mathrm{C}$ stock or soil bulk density, regardless of the soil depth sampled
(Table 3). Nevertheless, it is noteworthy that the 0.00-0.10 $\mathrm{m}$ soil depth accounted for $30 \%$ of average total soil C stock (0.00-0.40 m).

\section{Growth and $\mathrm{C}$ stock in the clone biomasses}

The clones MDX 624, CDC 312, and FDR 5788 exhibited greater height than the clones FX 3864 and PMB 1 (Figure 1a). In addition, MDX 624 was clearly larger than all others for DBH (Figure 1b). The high DBH and height of MDX 624 indicate this genetic material as the rubber tree clone most adapted to the soil and environmental conditions among the clones evaluated in the current study.

By considering the $\mathrm{C}$ stocks allocated to different tree components, it was clear that the MDX clone had the highest biomass $\mathrm{C}$ stock for most tree compartments, including the roots (Table 4).

\section{DISCUSSION}

\section{Soil C stocks and rubber tree clones}

Studies report that intra specific variation (genotype), age, type of soil, climate conditions, and management practices are important factors driving soil and tree biomass $\mathrm{C}$ accumulation in rubber tree

Table 2. Allometric models for estimating the carbon stocks in different tree biomass components

\begin{tabular}{llcc}
\hline Tree part & \multicolumn{1}{c}{ Model $^{(\mathbf{1})}$} & $\mathbf{R}^{\mathbf{2}}$ & CV \\
\hline & & 0.90 & 12.65 \\
Stem & $\ln \mathrm{C}=-4.07305+1.63781 \ln (\mathrm{DBH})+1.21724 \ln (\mathrm{Ht})$ & 0.74 & 29.43 \\
Branch & $\ln \mathrm{C}=-5.50875+4.2363 \ln (\mathrm{DBH})-1.10913 \ln (\mathrm{Ht})$ & 0.51 & 38.87 \\
Leaf & $\ln \mathrm{C}=-3.77312+2.80234 \ln (\mathrm{DBH})-1.01728 \ln (\mathrm{Ht})$ & 0.38 & 27.33 \\
Root & $\ln \mathrm{C}=-1.47682+1.44837 \ln (\mathrm{DBH})+0.40104 \ln (\mathrm{Ht})$ & 0.90 & 9.53 \\
Total & $\ln \mathrm{C}=-2.35205+2.43795 \ln (\mathrm{DBH})+0.11394 \ln (\mathrm{Ht})$ & 2 & 0 \\
\hline
\end{tabular}

(1) According to Fernandes et al. (2007). $\mathrm{R}^{2}$ : coefficient of determination; CV: coefficient of variation. 
Table 3. Carbon content, bulk density, and carbon stocks in the soil planted to rubber tree clones

\begin{tabular}{lcccccccc}
\hline Variable & Depth & FX 3864 & FDR 5788 & PMB 1 & MDX 624 & CDC 312 & Average & CV \\
\hline & $\mathrm{m}$ & & & & & & \\
Total organic C & $0.00-0.05$ & $20.0( \pm 1.3)$ & $19.9( \pm 1.1)$ & $19.1( \pm 1.9)$ & $17.0( \pm 1.1)$ & $18.1( \pm 1.8)$ & 18.8 & 23.0 \\
$\left(\mathrm{~g} \mathrm{~kg}^{-1}\right)$ & $0.05-0.10$ & $16.0( \pm 1.4)$ & $14.8( \pm 1.2)$ & $16.0( \pm 2.5)$ & $16.3( \pm 0.8)$ & $16.8( \pm 1.2)$ & 16.0 & 27.0 \\
& $0.10-0.20$ & $14.2( \pm 1.4)$ & $14.1( \pm 0.6)$ & $15.4( \pm 0.2)$ & $15.4( \pm 0.4)$ & $14.1( \pm 1.4)$ & 14.7 & 19.9 \\
& $0.20-0.40$ & $11.0( \pm 1.1)$ & $14.7( \pm 2.4)$ & $17.2( \pm 1.8)$ & $13.3( \pm 0.7)$ & $12.9( \pm 1.2)$ & 13.8 & 25.3 \\
& $0.00-0.05$ & $1.25( \pm 0.30)$ & $1.24( \pm 0.23)$ & $1.57( \pm 0.41)$ & $1.61( \pm 0.37)$ & $1.39( \pm 0.52)$ & 1.41 & 25.0 \\
Bulk density $_{\left(\mathrm{Mg} \mathrm{m}^{-3}\right)}$ & $0.05-0.10$ & $1.43( \pm 0.25)$ & $1.58( \pm 0.43)$ & $1.38( \pm 0.37)$ & $1.64( \pm 0.42)$ & $1.49( \pm 0.28)$ & 1.50 & 28.0 \\
& $0.10-0.20$ & $1.42( \pm 0.36)$ & $1.38( \pm 0.41)$ & $1.47( \pm 0.23)$ & $1.47( \pm 0.34)$ & $1.27( \pm 0.42)$ & 1.40 & 27.0 \\
& $0.20-0.40$ & $1.47( \pm 0.53)$ & $1.39( \pm 0.35)$ & $1.38( \pm 0.32)$ & $1.43( \pm 0.44)$ & $1.37( \pm 0.33)$ & 1.40 & 27.5 \\
$\mathrm{C} \mathrm{stocks}_{\left(\mathrm{Mg} \mathrm{ha}^{-1}\right)}$ & $0.00-0.05$ & $12.5( \pm 0.9)$ & $12.3( \pm 1.3)$ & $15.0( \pm 1.6)$ & $13.7( \pm 1.3)$ & $12.6( \pm 1.0)$ & 13.2 & 15.4 \\
& $0.05-0.10$ & $11.4( \pm 1.1)$ & $11.7( \pm 1.2)$ & $11.0( \pm 1.4)$ & $13.4( \pm 0.6)$ & $12.5( \pm 0.6)$ & 12.0 & 13.7 \\
& $0.10-0.20$ & $20.2( \pm 0.4)$ & $19.5( \pm 0.2)$ & $22.6( \pm 0.3)$ & $22.7( \pm 0.2)$ & $17.9( \pm 0.7)$ & 10.3 & 24.6 \\
& $0.20-0.40$ & $32.4( \pm 1.3)$ & $41.0( \pm 4.0)$ & $47.3( \pm 2.6)$ & $38.0( \pm 0.5)$ & $35.3( \pm 1.9)$ & 10.0 & 23.3 \\
& $0.00-0.40$ & $76.5( \pm 2.3)$ & $84.5( \pm 1.8)$ & $95.9( \pm 1.4)$ & $87.8( \pm 1.7)$ & $78.3( \pm 2.3)$ & 84.6 & 23.7 \\
\hline
\end{tabular}

The values of $\mathrm{C}$ and $\mathrm{C}$ stocks at each soil depth did not differ by the Tukey test at $5 \%$. Values in parenthesis represent the standard error of the mean. CV: coefficient of variation.
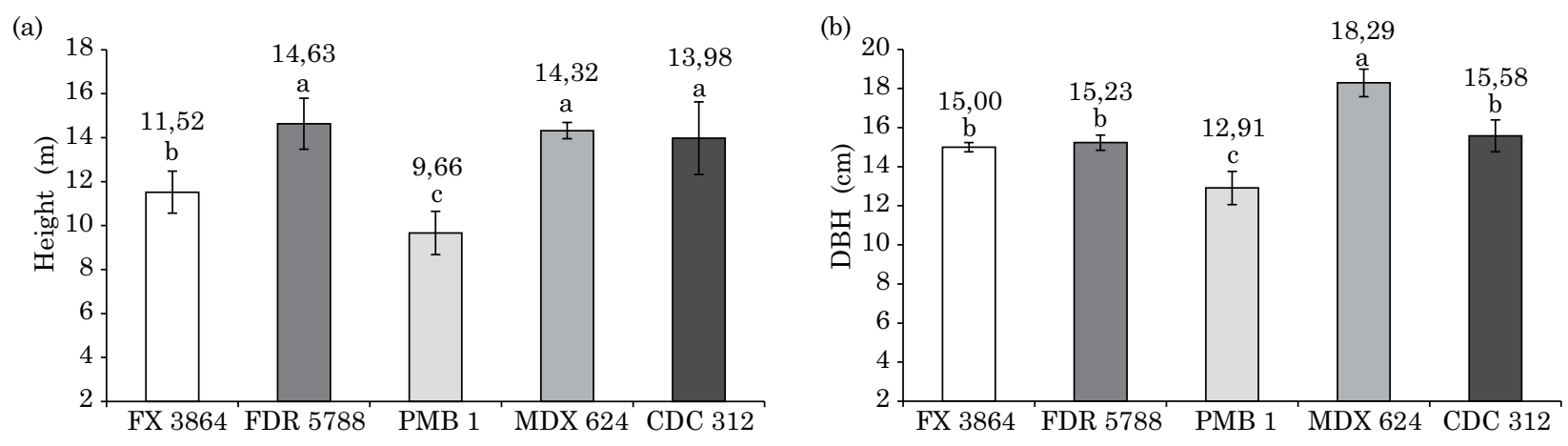

Clone

Figure 1. Total height of rubber tree clones (a) and diameter at breast height (DBH) (b). Different letters indicate that means differ by the Tukey test $(p<0.05)$. The bars associated with each mean indicate its standard error.

Table 4. Carbon stored in the different parts of the tree, total $\mathrm{C}$ biomass stored in the rubber tree clones, total $\mathrm{C}$ stock in soil $(0.00-0.40 \mathrm{~m})$, and total $\mathrm{C}$ stored (biomass + soil) in the plantings of rubber tree clones

\begin{tabular}{llllcccc}
\hline Clone & Stem & Branches & Leaves & Roots & Total biomass & Soil depth (0.00-0.40 m) & Total (biomass + soil) \\
\hline & \multicolumn{7}{c}{$\mathrm{Mg} \mathrm{ha}^{-1}$} \\
FX 3864 & $17.1 \mathrm{~b}$ & $18.2 \mathrm{ab}$ & $4.5 \mathrm{~b}$ & $8.9 \mathrm{~b}$ & $48.7 \mathrm{~b}( \pm 3.3)$ & $76.5 \mathrm{a}( \pm 2.3)$ & $125.2 \mathrm{c}( \pm 2.7)$ \\
FDR 5788 & $22.3 \mathrm{ab}$ & $14.9 \mathrm{~b}$ & $4.4 \mathrm{~b}$ & $9.3 \mathrm{~b}$ & $50.9 \mathrm{~b}( \pm 2.1)$ & $84.5 \mathrm{a}( \pm 1.8)$ & $135.4 \mathrm{~b}( \pm 2.0)$ \\
PMB 1 & $11.3 \mathrm{c}$ & $11.4 \mathrm{~b}$ & $3.4 \mathrm{~b}$ & $7.0 \mathrm{c}$ & $33.1 \mathrm{c}( \pm 1.9)$ & $95.9 \mathrm{a}( \pm 1.4)$ & $129.0 \mathrm{c}( \pm 1.8)$ \\
MDX 624 & $29.2 \mathrm{a}$ & $29.5 \mathrm{a}$ & $6.6 \mathrm{a}$ & $12.2 \mathrm{a}$ & $77.4 \mathrm{a}( \pm 2.0)$ & $87.8 \mathrm{a}( \pm 1.7)$ & $165.2 \mathrm{a}( \pm 2.1)$ \\
CDC 312 & $20.4 \mathrm{ab}$ & $14.0 \mathrm{~b}$ & $2.0 \mathrm{~b}$ & $8.0 \mathrm{~b}$ & $44.4 \mathrm{~b}( \pm 2.8)$ & $78.3 \mathrm{a}( \pm 2.3)$ & $122.7 \mathrm{c}( \pm 2.4)$ \\
Mean & 20.0 & 17.6 & 4.2 & 9.1 & 50.9 & 84.6 & 135.5 \\
CV (\%) & 28.7 & 30.3 & 20.4 & 22.5 & 20.5 & 23.7 & 24.5 \\
\hline
\end{tabular}

Values followed by the same letter in the column do not differ by the Tukey test at $5 \%$. Values in parenthesis are standard errors of the mean.CV: coefficient of variation. 
plantations (Yang et al., 2005; Carmo et al., 2006; Oliveira et al., 2006; Cotta et al., 2008; Egbe et al., 2012). However, a formal assessment has not been made of the relationship between aboveground biomass differences and variations in the $\mathrm{C}$ stock across the range of rubber tree clones. From the results obtained, low variation in soil $\mathrm{C}$ stocks and clear differences among rubber tree clones for plant biomass parameters can be inferred. Such results are contrary to those published in the literature, where differences in tree biomass are normally associated with the potential of greater $\mathrm{C}$ stocks in the soil (Wauters et al., 2008; Poorter et al., 2013).

It is impossible to precisely state that clones were not different from each other in terms of soil $\mathrm{C}$ stocks, since a clear tendency of more $\mathrm{C}$ in some soils was verified. Our results pointed out rubber tree clone MDX 624 had the highest estimated root biomass, which is known as an important $\mathrm{C}$ input to soil humus. High root biomass is thought to be linked to more $\mathrm{C}$ availability for microbial processes and to fungal biomass production, which are both important for the organic matter decomposition rate and, thus, for soil C stocks (Six et al., 2006). However, the fact root biomass in not measured but only estimated suggests that it is unlikely that the similarity among areas planted to rubber clones in terms of soil C stocks results from differences in terms of their root biomass systems in giving $\mathrm{C}$ input to the soil $\mathrm{C}$ pool.

In addition, the history of land use may have been influential in the soil $\mathrm{C}$ stock similarities among treatments. In our experiment, rubber tree clones were planted on soils which had been used as pasture for two years. Pastures, in turn, are characterized by their homogeneous spatial distribution of $\mathrm{C}$ across the soil depth, especially due to intense root profusion (Millard and Singh, 2010). This line of reasoning may be bolstered by the spacing of the rubber trees within the experimental plots $(8 \times 2.5 \mathrm{~m})$ which may have contributed to more homogeneous growth of grass species, associated with higher light availability to rubber trees.

Collectively, our results suggest no difference for soil C stocks among rubber tree clones, which means that the total area should be considered as a single stand of rubber trees in terms of soil C. It opens a discussion in making a comparison between the current results and those from other rubber tree experiments. For instance, our result for the pooled soil $\mathrm{C}$ stock $\left(84.6 \mathrm{Mg} \mathrm{ha}^{-1}\right)$, i.e, considering the soil layer from 0.00 to $0.40 \mathrm{~m}$, was quite similar to that reported by Yang et al. (2004), who observed a soil C stock of $90 \mathrm{Mg} \mathrm{ha}^{-1}$ at the same depth in soils planted to rubber trees. Likewise, de Blécourt et al. (2013) reported an average soil C stock of $60 \mathrm{Mg} \mathrm{ha}^{-1}$ across the first $0.30 \mathrm{~m}$ of a soil planted to rubber trees with different ages. Thus, though it is complicated to compare soil C stocks among different studies, especially because of contrasts in soil textures, and
Table 5. Soil carbon stocks in different areas planted to rubber trees, compared to the average $\mathrm{C}$ stock seen in this study

\begin{tabular}{lcccc}
\hline Source & Location & Age & Depth & $\begin{array}{c}\text { Carbon } \\
\text { stock }\end{array}$ \\
\hline & & year & $\mathrm{m}$ & $\mathrm{Mg} \mathrm{ha}^{-1}$ \\
Current study & Brazil (RJ) & 7 & $0.0-0.4$ & 86.4 \\
Yang et al. (2005) & China & 7 & $0.0-0.4$ & 126.5 \\
Wauters et al. (2008) & Brazil (MT) & 14 & $0.0-0.6$ & 105.5 \\
Saha et al. (2010) & India & 50 & $0.0-0.2$ & 35.7 \\
Li et al. (2012) & China & 18 & $0.0-0.2$ & 60.0 \\
de Blécourt et al. (2013) & China & 46 & $0.0-0.6$ & 60.1 \\
Nizami et al. (2014) & China & 40 & $0.0-0.6$ & 55.2 \\
Maggiotto et al. (2014) & Brazil (PR) & 14 & $0.0-0.6$ & 79.3 \\
\hline
\end{tabular}

because we had not made formal comparisons to the pasture, the overall $\mathrm{C}$ stock level we observed is in agreement with values found to be higher than pastures (Maggioto et al., 2014) (Table 5). Moreover, a study carried out in the same soil type used in the current study, Typic Hapludult, reported a value for pasture soil $\mathrm{C}$ stocks almost $50 \%$ lower than that found in the present study (Costa et al., 2009). In this sense, the results support the general findings that highlight planting of rubber trees as a potential type of land use that is able to increase soil C stocks compared to degraded pastures (Nizami et al., 2014).

\section{Aboveground part of the rubber tree as the main $\mathrm{C}$ pool of the plant}

Our results showed that the MDX 624 clone was clearly superior to all other clones for $\mathrm{C}$ biomass stock, which partially supports the hypothesis that clones differ from each other in C stocks. Interestingly, it was observed that the stem was responsible for most of total $\mathrm{C}$ biomass across all rubber clones (Figure 2). This is not in agreement with studies which have shown that the largest contributions to biomass $\mathrm{C}$ stocks in rubber tree plantations are typically from branches rather than from stems. For example, in assessing a 20-year-old rubber plantation, Carmo et al. (2006) reported that about $70 \%$ of the estimated tree C biomass was accounted for by the branches, whereas $23.4 \%$ was represented by the stem, and $7 \%$ by the leaves. Similarly, Fernandes et al. (2007), in assessing a 12-year-old rubber plantation, reported a higher contribution of branches to total $\mathrm{C}$ biomass (35\%) than the contributions made by stems (30\%), roots $(30 \%)$ and leaves $(4 \%)$. Such results do not agree with those observed in the present study. This may be due to the fact that the rubber tree clones in our experiment are still young since, in our study, measurements were made at seven years from establishment. Authors have pointed out that in younger rubber tree plantations the 
stem contribution to total $\mathrm{C}$ biomass is typically higher than that from the branches and vice-versa (Carmo et al., 2006; Fernandes et al., 2007).

Comparing the present total $\mathrm{C}$ biomass value to that from other experiments in rubber tree plantations, carried out under similar environmental conditions, a higher $\mathrm{C}$ biomass may be observed in this study than the biomass observed by Wauters et al. (2008). In contrast, the observed total $\mathrm{C}$ biomass was about 40,17 and $18.6 \%$ lower than the biomass values found by Cotta et al (2006), Fernandes et al. (2007), and Maggiotto et al. (2014), respectively. Though a lower total $\mathrm{C}$ biomass stock was found in our study compared to other studies, in general, the rubber tree plants in this study exhibited a $\mathrm{C}$ accumulation rate superior to that of other studies (Table 6).

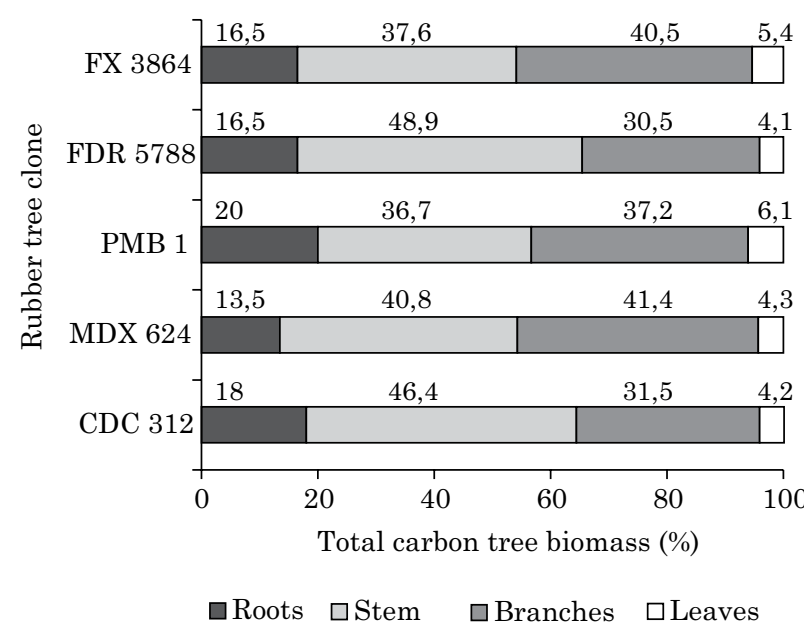

Figure 2. Individual contribution (percentage) of tree biomass components across different rubber tree clones.

Table 6. Average tree carbon stocks in the biomasses of different rubber trees

\begin{tabular}{|c|c|c|c|c|}
\hline Source & Location & Age & $\begin{array}{c}\text { Carbon } \\
\text { stocks }\end{array}$ & $\begin{array}{c}\text { Accumulation } \\
\text { rate }\end{array}$ \\
\hline & & year & $\mathrm{Mg} \mathrm{ha}^{-1}$ & $\mathrm{Mg} \mathrm{ha}^{-1} \mathrm{yr}^{-1}$ \\
\hline Current study & Brazil (RJ) & 7 & $50.9^{(1)}$ & 7.3 \\
\hline Yang et al. (2005) & China & 16 & $66.4^{(1)}$ & 4.2 \\
\hline Cotta et al. (2008) & Brazil (BA) & 34 & $85.0^{(1)}$ & 2.5 \\
\hline $\begin{array}{l}\text { Fernandes et al. } \\
\text { (2007) }\end{array}$ & Brazil (MG) & 12 & $62.0^{(1)}$ & 5.2 \\
\hline Cheng et al. (2007) & China & 30 & $90.5^{(1)}$ & 3.0 \\
\hline Wauters et al. (2008) & Brazil (MT) & 14 & $41.7^{(1)}$ & 3.0 \\
\hline Nizami et al. (2014) & China & 40 & $114.8^{(1)}$ & 2.9 \\
\hline $\begin{array}{l}\text { Maggiotto et al. } \\
\text { (2014) }\end{array}$ & Brazil (PR) & 15 & $62.5^{(2)}$ & 4.2 \\
\hline
\end{tabular}

(1) Using allometric equations; ${ }^{(2)}$ destructive sampling.

\section{Total carbon stock differences are predominantly biomass stock differences}

In a previous paragraph, it was stated that the higher C biomass stock for the MDX 624 clone partially supported the hypothesis that rubber tree clones differ in terms of $\mathrm{C}$ stock. This is important to emphasize because it shows that only one of the components of the total C stock (biomass C stock + soil C stock) was clearly dissimilar among clones. Thus, as one compares clones in terms of total $\mathrm{C}$ stock, it is expected that the differences observed among clones will be more a result of the aboveground $\mathrm{C}$ stock component rather than the belowground component. This expectation was confirmed by the results of the total $\mathrm{C}$ stock (Table 4) and suggests that at the current stage of planting rubber tree clones, differences in biomass $\mathrm{C}$ stock are easier to detect among clones than differences among clones in terms of soil $\mathrm{C}$ stock.

\section{CONCLUSIONS}

The rubber tree clones differ from each other in terms of total carbon stocks. However, this contrast seems to be predominately related to the carbon stock in the tree biomass. Amounts of carbon stored in the MDX 624 rubber tree clone exceed those determined in other rubber tree clones.

Differences in carbon stocks among the clones is mainly due to carbon stored in plant biomass, and carbon stock in the aboveground tree biomass and the belowground compartments contribute differently to the total plant carbon stock, at 36.2 and $63.8 \%$ respectively. This shows that, irrespective of clone differences, the right choice of a rubber tree clone is a win-win strategy for sequestering carbon from the air and storing it in plants since soil carbon stocks $(0.0-0.4 \mathrm{~m})$ are not affected by the rubber clones investigated.

\section{REFERENCES}

Borracha Natural Brasileira. Borracha natural. [Accessed: 2014 Feb. 7]. Available at: http://www.borrachanatural.agr.br/ borrachanatural.php.

Carmo CAFS, Manzatto CV, Alvarenga AP, Tosto SG, Lima JAS, Kindel A, Motta F. Biomassa e estoque de carbono em seringais implantados na Zona da Mata de Minas Gerais. In: Alvarenga AP, Carmo CAFS, editores. Sequestro de carbono: quantificação em seringais de cultivo e na vegetação natural. Viçosa, MG: Universidade Federal de Viçosa; 2006. p.77-101.

Cheng C, Wang R, Jiang J. Variation of soil fertility and carbon sequestration by planting Hevea brasiliensis in Hainan Island, China. J Environ Sci. 2007;19:348-52. 
Costa OV, Cantarutti RB, Fontes LEF, Costa LM, Nacif PGS, Faria JC. Estoque de carbono do solo sob pastagem em área de tabuleiro costeiro no sul da Bahia. R Bras Ci Solo. 2009;33:1137-45.

Cotta MK, Jacovine LAG, Paiva HN, Soares CPB, Virgens Filho AC, Valverde SR. Quantificação de biomassa e geração de certificados de emissões reduzidas no consórcio seringueira-cacau. R Árvore. 2008;32:969-78.

de Blécourt M, Brumme R, Xu J, Corre MD, Veldkamp E. Soil carbon stocks decrease following conversion of secondary forests to rubber (Hevea brasiliensis) plantations. PLoS One. 2013;8:e69357.

Egbe AE, Tabot PT, Fonge BA, Bechem E. Simulation of the impacts of three management regimes on carbon sinks in rubber and oil palm plantation ecosystems of South- Western Cameroon. J Ecol Nat Environ. 2012;4:154-62.

Empresa Brasileira de Pesquisa Agropecuária - Embrapa. Centro Nacional de Pesquisa de Solo. Manual de métodos de análise de solos. $2^{\text {a }}$.ed. Rio de Janeiro: 1997.

Empresa Brasileira de Pesquisa Agropecuária - Embrapa. Centro Nacional de Pesquisa de Solos. Manual de métodos de análise de solos. $2^{\text {a }}$.ed. Rio de Janeiro: 2011.

Fernandes TJG, Soares CPB, Jacovine LAG, Alvarenga AP. Quantificação do carbono estocado na parte aérea e raízes de Hevea sp., aos 12 anos de idade, na Zona da Mata Mineira. R Árvore. 2007:31:657-65.

Food and Agriculture Organization of the United Nations - FAO. Global forest resources assessment. Roma: 2010. (FAO Forestry Paper, 163).

Freixo AA, Machado PLOA, Guimarães CM, Silva CA, Fadigas FS. Estoques de carbono e nitrogênio e distribuição de frações orgânicas de Latossolo do Cerrado sob diferentes sistemas de cultivo. R Bras Ci Solo. 2002;26:425-34.

Gonçalves PS, Marques JRB. Melhoramento genético da seringueira: passado, presente e futuro. In: Alvarenga AP, Carmo CAFS, editores. Seringueira. Viçosa, MG: Epamig; 2008. p.399-534

Li H, Ma Y, Liu W, Liu W. Soil changes induced by rubber and tea plantation establishment: Comparison with tropical rain forest soil in Xishuangbanna, SW China. Environ Manage. 2012;50:837-48.

Maggiotto SR, Oliveira D, Marur CJ, Stivari SMS, Leclerc M, Wagner-Riddle C. Potential carbon sequestration in rubber tree plantations in the northwestern region of the Paraná State, Brazil. Acta Sci Agron. 2014;36:239-45.

Millard P, Singh B. Does grassland vegetation drive soil microbial diversity? Nutr Cycl Agroecosyst. 2010;88:147-58.
Naime UJ, Lumbreras JF, Motta PEF. Zoneamento agroecológico da seringueira no estado do Rio de Janeiro. In: Oliveira AB, Carmo CAFS, Cruz RB, editores. A cultura da seringueira no estado do Rio de Janeiro: perspectivas e recomendações técnicas. Niterói, [RJ]: Pesagro; 2009. p.37-55.

Nizami SM, Yiping Z, Liqing S, Zhao W, Zhang X. Managing carbon sinks in rubber (Hevea brasilensis) plantation by changing rotation length in SW China. PLoS One. 2014;9:e115234.

Oliveira D, Pereira JP, Ramos A. Carbono na biomassa e na respiração do solo em plantio comercial de seringueira no Paraná. In: Alvarenga AP, Carmo CAFS, editores. Sequestro de carbono - quantificação em seringais de cultivo e na vegetação natural. Viçosa, MG: Universidade Federal de Viçosa; 2006. p.201-14.

Poorter H, Niklas KJ, Reich PB, Oleksyn J, Poot P, Mommer L. Biomass allocation to leaves, stems and roots: meta-analyses of interspecific variation and environmental control. New Phytol. 2012;193:30-50.

Ramachandran NPK, Kumar BM, Vimala DN. Agroforestry as a strategy for carbon sequestration. Review Article. J Plant Nutr Soil Sci. 2009;172:10-23.

Saha SK, Ramachandra Nair PK, Nair VD, Mohan Kumar B. Carbon storage in relation to soil size-fractions under tropical tree-based land-use systems. Plant Soil. 2010;328:433-46.

Six J, Frey SD, Thiet RK, Batten KM. Bacterial and fungal contributions to carbon sequestration in agroecosystems. Soil Sci Soc Am J. 2006;70:555-69.

Strassburg BBN, Latawiec AE, Barioni LG, Nobre CA, Silva VP, Valentim JF, Vianna M, Assad ED. When enough should be enough: improving the use of current agricultural lands could meet production demands and spare natural habitats in Brazil. Global Environ Change. 2014;28:84-97.

Soil Survey Staff. Keys to soil taxonomy. Washington, DC: USDA/NRCS; 2010.

Wauters JB, Coudert S, Grallien E, Jonarda M, Ponettea Q. Carbon stock in rubber tree plantations in Western Ghana and Mato Grosso (Brazil). For Ecol Manage. 2008;255:2347-61.

Yang J, Huang J, Pan Q, Tang J, Han X. Long-term impacts of land-use change on dynamics of tropical soil carbon and nitrogen pools. J Environ Sci. 2004;16:256-61.

Yang JC, Huang JH, Tang JN, Pan QM, Han XG. Carbon sequestration in rubber tree plantations established on former arable lands in Xishuangbanna, SW China. Chinese J Plant Ecol. 2005;29:296-303.

Yeomans JC, Bremner JM. A rapid and precise method for routine determination of organic carbon in soil. Commun Soil Sci Plant Anal. 1988;19:1467-76. 